\title{
Goiter in fetus without maternal thyroid disease: a case report
}

\author{
Önder Sakin', Bülent Kars², Yasemin Karageyim Karşıdağ ${ }^{3}$, Cenk Demir², Esra Esim Büyükbayrak \\ ${ }^{\prime}$ Department of Gynecology \& Obstetrics, Dr. Liitfi Kirdar Kartal Training and Research Hospital, Istanbul, Turkey \\ ${ }^{2}$ Private Dragos Gïlen Medical Center, Istanbul, Turkey \\ ${ }^{3}$ Health High School, Kirklareli University, Kırklareli, Turkey
}

\begin{abstract}
Objective: The aim is to discuss fetal hypothyroidism which we consider that its prenatal diagnosis and treatment is significant since it may cause physical and mental growth retardation in affected fetuses.

Case: A fetal goiter case was presented which was found during routine ultrasonographic examination at 30 weeks of gestation. The pregnant women had no thyroid history and all thyroid function tests were normal including thyroid auto-antibodies in laboratory tests. In the Doppler ultrasonography, a thyroid gland grown diffusely with increased bloodshot was observed in the fetus. By these findings, it was considered that fetal goiter would be caused by fetal hypothyroidism. Amniocentesis or cordocentesis was recommended as final diagnosis, but the patient refused invasive procedures.

Conclusion: Doppler and ultrasonographic findings are important for fetal goiter diagnosis and follow-up.
\end{abstract}

Keywords: Fetal goiter, ultrasonography, prenatal diagnosis.

\section{Özet: Maternal tiroid hastalığı olmayan fetüste guatr: Olgu sunumu}

Amaç: Amaç, etkilenen fetüslerde fiziksel ve zihinsel gelişme geriliklerine yol açabildiği için prenatal tanı ve tedavisinin önemli olduğunu düşündüğümüz fetal hipotiroidizmi güncel bilgiler ışığında tartışmaktır.

Olgu: Otuz haftalık gebe iken rutin ultrasonografi incelemesinde tespit edilmiş bir fetal guatr olgusu sunuldu. Gebenin özgeçmişinde tiroid hastalığı öyküsü mevcut değildi ve laboratuvar testlerinde tiroid otoantikorları da dahil tüm tiroid fonksiyon testleri normaldi. Doppler ultrasonografide fetüste diffüz olarak büyümüş ve kanlanması artmıs tiroid bezi izlendi. Bu bulgularla fetal guatrın fetal hipotiroidizme bağlı olabileceği düşünüldü. Kesin tanı için amniyosentez veya kordosentez önerilen hasta invazif girişimleri kabul etmedi.

Sonuç: Fetal guatr tanı ve izleminde ultrasonografi ve Doppler bulguları önemlidir.

Anahtar sözcükler: Fetal guatr, ultrasonografi, prenatal tanı.

\section{Introduction}

Thyroid disorders are the common endocrine disorders seen during perinatal period. While maternal thyroid anomalies can be diagnosed easily by maternal serum tests, it is considerably difficult to determine and diagnose fetal goiter. ${ }^{[1]}$ Different biochemical disorders in the thyroid hormone synthesis or maternal autoimmune thyroid diseases may cause fetal goiter. ${ }^{[2]}$
Goiter may be related with fetal hypothyroidism or hyperthyroidism. Many authors believe the necessity to determine fetal thyroid function in order to initiate early treatment process for this condition. ${ }^{[3]}$

Weiner et al. reported in 1980 for the first time that they diagnosed fetal goiter by prenatal sonography method. ${ }^{[4]}$

Presence of a large thyroid gland on fetal neck region may cause a difficult delivery due to polyhydramnios by
Correspondence: Önder Sakin, MD. İstanbul Dr. Lütfi Kırdar Kartal Eğit. ve Araş. Hast., Kadın Hastalıkları ve Doğum Kliniği, İstanbul, Turkey. e-mail: sakin-onder@hotmail.com Received: October 29, 2014; Accepted: December 20, 2014

Please cite this article as: Sakin Ö, Kars B, Karageyim Karşıdağ Y, Demir C, Esim Büyükbayrak E. Goiter in fetus without maternal thyroid disease: a case report. Perinatal Journal 2015;23(1):65-69.

(c)2015 Perinatal Medicine Foundation
Available online at: www.perinataljournal.com/20150231004 doi: $10.2399 /$ prn.15.0231004 QR (Quick Response) Code:

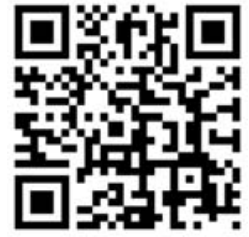


esophageal and tracheal pressure and also hyperextension on neck by mass effect. ${ }^{[5]}$

Fetal hypothyroidism generally depends on antithyroid treatments or endemic iodine deficiency. Their incidence rate is very low without maternal disease. $^{[6]}$

As in the world, hypothyroidism screening is carried out successfully during newborn period in Turkey and successful treatments are performed as of the early period.

However, hypothyroidism developing in fetal period is very significant for the life. The possibility of congenital hypothyroidism which causes mental retardation but mostly possible to treat is 1 out of each 4000 live birth. ${ }^{[7]}$ Fetal goiter hypothyroidism forming only $10-15 \%$ of all congenital hypothyroidism cases is rarely seen (one out of 4000) ${ }^{[8]}$ Thanks to the development in ultrasonography technology, even though it is a rare case, the number of reports prepared for fetal goiter investigations increases day by day. ${ }^{[9]}$

\section{Case Report}

The 28-year-old patient having her first pregnancy admitted to our hospital for examination on her 30 weeks of gestation. A great homogeneous mass was detected on the anterior side of fetal neck during ultrasonographic examination. The mother was married to her second cousin. There was no thyroid disease in the history or family history of the mother. She had no

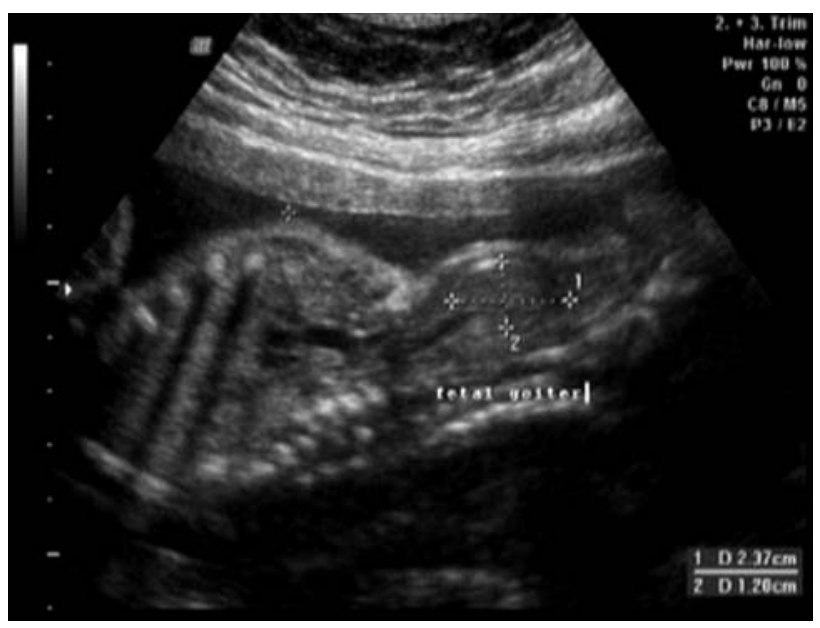

Fig. 1. 2D ultrasound image of fetal goiter. iodine or thyroid drug history. In the maternal examination, no examination finding related with thyroid disease was found. There was also no anomaly in routine gestational analyses.

In the ultrasonographic examination, a wide, symmetric and bilobulated mass pressuring trachea on the anterior side of the fetal neck $(47.4 \times 32.2 \times 26.6 \mathrm{~mm})$ (Fig. 1) and mild polyhydramnios were found. Due to its pressure on esophagus and trachea, angle changes made by growing thyroid tissue on the background, deterioration in normal traces and concomitant polyhydramnios, we suspected of the presence of goiter. The mass was in very vascularized appearance in the Doppler examination (Fig. 2). Fetal heart rate was 220 bpm. It was seen as a tachycardia in sinusoidal type. No other anomaly was observed in the fetus. Fetal growth and movements were normal. Maternal serum thyroid function tests and thyroid ultrasound results were normal. The mother was euthyroid, free T3 was $3.34 \mathrm{pg} / \mathrm{ml}$, free T4 was 2.30 $\mathrm{ng} / \mathrm{dl}$ and TSH was $3.86 \mathrm{IU} / \mathrm{ml}$. Anti-thyroid antibodies were negative. The family was informed about fetal condition and prognosis. The family refused to have any invasive procedure such as amniocentesis, cordocentesis and/or intraamniotic thyroxine treatment. Fetal condition, cardiac activity, fetal development, thyroid dimensions and fetal thyroid bleeding were followed up by color Doppler. No pathology was seen to explain fetal tachycardia. In the follow-ups during further weeks, fetal heart rate was observed within normal ranges. Since newborn cardiac evaluation was not characterized,

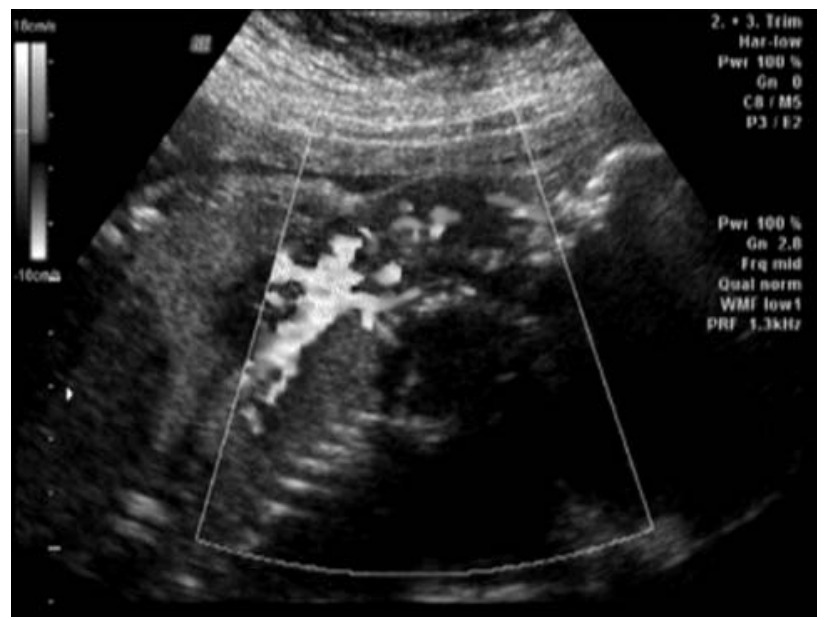

Fig. 2. Doppler ultrasound image of fetal goiter. 
no further evaluation and diagnosis method was required.

The patient delivered a male baby (2600 g) by cesarean since the delivery began on 36 weeks of gestation and due to pelvic contraction. One-minute APGAR score was 6, and five-minute score was 7 . There was bilobulated goiter; however, it caused no obstruction in the airway of newborn and resuscitation was not required. The baby had no problem with postnatal respiratory adaptation. Postnatal color Doppler examination confirmed enlarged thyroid gland.

Iodothyronines in cord blood and TSH measurements confirmed the diagnosis of hypothyroidism. As of the first neonatal day, oral $50 \mathrm{mcg} /$ day thyroxine hormone treatment was initiated. Fetal tachycardia was not observed after the delivery. Weight, height and psychomotor developments of child were normal in the first 6 months, and the follow-ups have been maintained.

\section{Discussion}

A great goiter may cause fetal neck hyperextension resulting with malpresentation and complicated delivery process. The trachea may be obstructed after birth due to goiter, and this may cause asphyxia and death. During the delivery, pediatric anesthesia and pediatric ENT experts should be present in the delivery room with their intubation and bronchoscopy devices. Neonatal screening programs are successfully used in the diagnosis of congenital hypothyroidism just after the delivery and normal development is remedied significantly by early postnatal treatment. On the other hand, some babies exposed to congenital hypothyroidism have difficulties and delays in neuromotor, perception and language abilities despite the postnatal early treatment. Therefore, it is important to place emphasis on prenatal treatment of congenital hypothyroidism. ${ }^{[10]}$

The enlargement of thyroid gland can be seen by ultrasonography on the anterior side of the fetal neck as homogenous straight masses with high echogenicity and distinct edges. The mass can be bilobulated and its size can enlarge up to $30-35 \mathrm{~mm} .{ }^{[11]}$ There are also nomograms for thyroid dimensions appropriate to related fetal weeks of gestation.

It can be considered that the treatment of fetal hypothyroidism during intrauterine period is controversial; however, it has been reported that the treatment of fetuses with large goiter is indicated. The reason is that it may cause obstruction due to trachea, and the mechanic problems during delivery may cause morbidity. ${ }^{[12]}$

One of the prenatal examinations is Doppler ultrasound. It can be seen in the Doppler ultrasound that neck vessels spread around soft tissue mass. If it is hypervascular, the increase in the diameters of carotid and jugular veins can be seen. In case of hyperthyroidism, the diffuse increased flow in the gland can be seen. In case of hypothyroidism, peripheral flow around the gland can be observed. $^{[6]}$

However, in another source, it was reported that the detection of the increase in blood flow towards fetal thyroid is an unreliable finding of hyperthyroid, and even surprisingly, that increased blood flow was found by using power Doppler for hypothyroidism. ${ }^{[13]}$ Consequently, it is not possible to make clear interpretation about thyroid functions just based on Doppler findings.

Amniotic fluid concentrations of TSH reflect fetal serum levels properly. However, Bruner and Dellinger asserted that fetal cord blood measurements are more reliable, and the evaluation made by amniocentesis is suspicious. ${ }^{[14]}$ Fetal thyroid functions can be evaluated properly by fetal blood sampling method; however, this method is more risky since it has a $1 \%$ risk of fetal death. ${ }^{[15]}$ However, the publications stating that the determination of thyroid hormone levels found through amniotic fluid is not reliable for the diagnosis are predominant. $^{[16]}$

The association of fetal goiter with chromosomal anomalies was analyzed, and it was found that it has no association with aneuploidy. However, in the Pendred syndrome, hearing loss in sensorineural type and goiter can be seen. It is an autosomal recessive condition and thyroid hormone synthesis is insufficient. ${ }^{[6]}$

Different approaches may be applied in fetal treatment. If fetal goiter is detected in pregnant women receiving treatment for maternal hyperthyroidism, decreasing the drug dose by considering the placental transition of drugs and following up fetal thyroid gland measurements have been recommended. If fetal goiter sizes decrease as a result of this treatment, it is recommended to perform no procedure. However, if goiter continues to enlarge or no respond is received, the fetus may have hyperthyroid and it is suggested to analyze direct fetal thyroid hormones by doing cordocentesis. If fetal hyperthyroidism is found as a result, maternal treatment dose is increased until a fetal 
respond is received. Propylthiouracil is recommended as the drug. ${ }^{[6]}$

Intra-amniotic levothyroxine injection as the least invasive approach in fetal treatment referred by Abuhamad et al. is a treatment method accepted widely so far. ${ }^{[17]}$ In this sense, Medeiros-Neto et al. found increased TSH and decreased sT4 in the cordocentesis analysis of the fetus with $29 \times 34 \mathrm{~mm}$ fetal goiter at 23 weeks of gestation, and they performed intrauterine levothyroxine treatment. As a result of $400 \mathrm{mcg}$ levothyroxine single-dose injection, the size of thyroid was found as $4.8 \times 12.5 \mathrm{~cm}$ at the end of 4 weeks and the treatment was considered as sufficient. ${ }^{[18]}$

The treatment dose estimation recommended by Abuhamad et al. is to do intraamniotic levothyroxine injection with the dose of $10 \mathrm{mcg} / \mathrm{kg}$ according to the birth weight. ${ }^{[17]}$

However, as a result of different treatments and case reports later, Ribault et al. evaluated the treatments of 18 compiled cases. For 1-4 weeks, they made 1-7 injections and found that there was $70-800 \mathrm{mcg}$ dose difference in each application and $3-23 \mathrm{mc} / \mathrm{kg}$ difference in each protocol. Also, fetal hormonal analysis was performed through amniotic fluid in some cases while it was done through cord blood in some other cases. In the conclusion section of that study, the authors reported that there has been no certain consensus on the treatment of fetal hypothyroidism. ${ }^{[16]}$

In their recent case report, Khamisi et al. found maternal hormones within normal ranges and fetal TSH as $>100 \mathrm{mU} / \mathrm{l}$ in pregnant women with fetal goiter at 18 weeks of gestation, and they administered intraamniotic thyroxine for 9 times at intervals of 7-10 days between 24 and 33 weeks of gestation. They administered $10 \mathrm{mcg} / \mathrm{kg}$ in the first 6 applications, and $5 \mathrm{mcg} / \mathrm{kg}$ in the last 3 applications. Fetal development was normal; however, the delivery was made by cesarean at 34 weeks of gestation due to the suspicion of chorioamnionitis. Since TSH was higher than $596 \mathrm{mU} / \mathrm{L}$ (reference values: $8.0 \pm 5.12$ ) in the cord blood during delivery, thyroxine treatment was initiated just after the delivery. In the conclusion section of the investigation, it was indicated that new investigations are required for intraamniotic thyroxine treatment. ${ }^{[2]}$

\section{Conclusion}

As a conclusion, ultrasound and Doppler examinations, diagnosing and following up fetal goiter are of vital importance. Fetal hypothyroidism is a negative pathology for the development of central nervous system and physical and mental development. Fetal goiter which is not present in the ultrasound during the early periods but becomes evident in the advanced weeks of gestation should not be overlooked. Mental retardation and other development disorders can be prevented by early diagnosis and treatment. Therefore, we believe that it will be useful to remember fetal goiter in the ultrasonographic screenings even during advanced weeks of gestation.

Conflicts of Interest: No conflicts declared.

\section{References}

1. Singh PK, Parwin CA, Gronowski AM. Establishment of reference intervals for markers of fetal thyroid status in amniotic fluid. J Clin Endocrinol Metab 2003;88:4175-9.

2. Khamisi S, Lindgren $P$, Karlssson FA. A rare case of dyshormonogenetic fetal goiter responding to intra-amniotic thyroxine injections. Eur Thyroid J 2014;3:51-6.

3. Perrotin F, Sembely-Taveau C, Haddad G, Lyonnais C, Lansac J, Body G. Prenatal diagnosis and early in utero management of fetal dyshormonogenetic goiter. Eur J Obstet Gynecol Reprod Biol 2001;94:309-14.

4. Weiner S, Scharf JI, Bolognese RJ, Librizzi RJ. Antenatal diagnosis and treatment of a fetal goiter. J Reprod Med 1980; 24:39-42.

5. Davidson KM, Richards DS, Schatz DA, Fisher DA. Successful in utero treatment of fetal goiter and hypothyroidism. N Engl J Med 1991;324:543-6.

6. Paula JW, Anne K, Roya S, Janice LB, Karen YO, Michael DP. Face and neck anomalies - Goiter. Diagnostic imaging obstetrics. 2nd edition. Utah Amirsys 2013. p: 4/54-5.

7. Delange F. Neonatal screening for congenital hypothyroidism: results and perspectives. Horm Res 1997;48:51-61.

8. Fisher DA. Fetal thyroid function: diagnosis and management of fetal thyroid disorders. Clin Obstet Gynecol 1997; 40:16-31.

9. Meideros-Neto GA, Stanbury JB. Inherited Disorders of the Thyroid System. Boca Raton: CRC Pres; 1994; p: 1-218.

10. Morine M, Takeda T, Minekawa R, Sugiyama T, Wasada K, Mizutani T, et al. Antenatal diagnosis and treatment of a case of fetal goitrous hypothyroidism associated with high-output cardiac failure. Ultrasound Obstet Gynecol 2002;19:506-9.

11. Cunningham FG, Leveno KJ, Bloom SL, Hauth JC, Rouse DJ, Spong CY. Tiroid ve diğer endokrin bozukluklar. Williams Obstetrik. 23. baskı. Istanbul: Nobel Tip Kitapevi; 2010. p. 1128-35.

12. Mestman JR. Tyroid and parathyroid diseases in pregnancy. In: Gabbe SG, Niebly JR, Simpson JL, editors. Obstetrics: normal and problem pregnancies. 5 th edition. London: Churchill Livingstone; 2007. p.1023-9.

13. Merz E. Obstetrik ve jinekolojide ultrason. Çeviri: Özden S. 2. baskı. Cilt 1. İstanbul: Doğan Tip Kitapevi; 2002. p. 247-52. 
14. Bruner JP, Dellinger EH. Antenatal diagnosis and treatment of fetal hypothyroidism. A report of two cases. Fetal Diagn Ther 1997;12:200-4.

15. Simsek M, Mendilcioglu I, Mihci E, Karagüzel G, Taskin O. Prenatal diagnosis and early treatment of fetal goitrous hypothyroidism and treatment results with two-year followup. J Matern Fetal Neonatal Med 2007;20:263-5.

16. Ribault V, Castanet M, Bertrand AM, Guibourdenche J, Vuillard E, Luton D, et al.; French Fetal Goiter Study Group. Experience with intraamniotic thyroxine treatment in nonimmune fetal goitrous hypothyroidism in 12 cases. J Clin Endocrinol Metab 2009;94:3731-9.

17. Abuhamad AZ, Fisher DA, Warsof SL, Slotnick RN, Pyle PG, Wu SY, et al. Antenatal diagnosis and treatment of fetal goitrous hypothyroidism: case report and review of the literature. Ultrasound Obstet Gynecol 1995;6:368-71.

18. Medeiros-Neto G, Bunduki V, Tomimori E, Gomes S, Knobel M, Martin RT, et al. Prenatal diagnosis and treatment of dyshormonogenetic fetal goiter due to defective thyroglobulin synthesis. J Clin Endocrinol Metab 1997;82:4239-42. 